\title{
EDUCAÇÃO INTEGRAL E EDGAR MORIN: ASSOCIAÇÕES PARA SE PENSAR OS DIFERENTES ESPAÇOS E TEMPOS EDUCATIVOS
}

\author{
INTEGRAL EDUCATION AND EDGAR MORIN: ASSOCIATIONS TO THINK ABOUT THE \\ DIFFERENT EDUCATIONAL SPACES AND TIMES
}

\section{EDUCACIÓN INTEGRAL Y EDGAR MORIN: ASOCIACIONES PARA PENSAR LOS DIFERENTES ESPACIOS Y TIEMPOS EDUCATIVOS}

\author{
Diovane de César Resende Ribeiro ${ }^{1}$ \\ Wagner Wey Moreira² \\ Monica Izilda da Silva ${ }^{3}$
}

\section{RESUMO}

Este trabalho é recorte do referencial teórico de uma dissertação de mestrado do Programa de PósGraduação em Educação da Universidade Federal do Triângulo Mineiro. A pesquisa foi desenvolvida no período de 2018 a 2020. Para esta produção apresentamos as bases epistemológicas utilizadas em nossa investigação, pautadas na literatura referente à Educação Integral e nas produções desenvolvidas por Edgar Morin sobre a Teoria da Complexidade. Neste trabalho tivemos como objetivo associar a Teoria da Complexidade e a Educação Integral para subsidiar possíveis articulação(ões) das instituições formais de ensino com os diferentes espaços do seu entorno. Como considerações finais, entendemos que o ser humano compõe a tríade indivíduo/sociedade/espécie, o qual pertence a uma comunidade e ao mesmo tempo é resultado de inúmeras metamorfoses e evoluções históricas, biológicas, culturais e sociais. Há outros espaços e tempos educativos, os quais contribuem de maneira direta ou indireta para 0 desenvolvimento das diferentes capacidades dos sujeitos habitantes do território.

PALAVRAS-CHAVE: Educação Integral. Edgar Morin. Espaços e tempos educativos.

\section{ABSTRACT}

This paper is a cut of the theoretical framework of a master's thesis of the Postgraduate Programme in Education of the Federal University of the Triângulo Mineiro. The research was developed in the period from 2018 to 2020. For this production we present the epistemological bases used in our research, guided by the literature referring to Integral Education and the productions developed by Edgar Morin about Complexity Theory. In this work we aimed to associate Complexity Theory and Integral Education to support possible articulation(s) of formal educational institutions with the different spaces around them. As

\footnotetext{
1 Doutorando em Educação pelo Programa de Pós-Graduação em Educação da Universidade Federal do Triângulo Mineiro (PPGE-UFTM). Graduado em Pedagogia pela Universidade de Uberaba (UNIUBE). Especialista em Educação e Escola em tempo integral: desafios e perspectivas pela Faculdade Educacional da Lapa (FAEL). Mestre em Educação pelo Programa de Pós-Graduação em Educação da Universidade Federal do Triângulo Mineiro (PPGE-UFTM). E-mail: diovane.resende@uberabadigital.com.br

2 Possui graduação em Educação Física pela Universidade Metodista de Piracicaba (1973), graduação em Pedagogia Habilitação em Administração e Orientação Educacional pela Faculdade de Educação Osório Campos-RJ (1978), graduação em Pedagogia, Habilitação em Supervisão Escolar pela Faculdade de Educação Dom Bosco (1983), mestrado em Educação (Filosofia) pela Universidade Metodista de Piracicaba (1985), doutorado em Educação (Psicologia Educacional) pela Universidade Estadual de Campinas (1990) e Livre Docência pela Universidade Estadual de Campinas (1993). E-mail: wagner.moreira@uftm.edu.br

${ }^{3}$ Doutoranda em Educação pelo Programa de Pós-Graduação em Educação da Universidade Federal do Triângulo Mineiro (UFTM).Mestra em Educação pelo Programa de Pós-Graduação em Educação da Universidade Federal do Triângulo Mineiro (UFTM). E-mail: monicaizilda.silva@gmail.com
} 
final considerations, we understand that the human being makes up the triad individual/society/species, which belongs to a community and at the same time is the result of numerous metamorphoses and historical, biological, cultural and social evolutions. There are other educational spaces and times that contribute directly or indirectly to the development of the different capacities of the subjects that inhabit the territory.

KEYWORDS: Integral Education. Edgar Morin. Educationalspacesand times.

\section{RESUMEN}

Este trabajo forma parte del marco teórico de una tesis de maestría del Programa de Posgrado en Educación de la Universidad Federal del Triângulo Mineiro. La investigación se realizó de 2018 a 2020. Para esta producción, presentamos las bases epistemológicas utilizadas en nuestra investigación, con base en la literatura sobre Educación Integral y en las producciones desarrolladas por Edgar Morin sobre la Teoría de la Complejidad. En este trabajo se buscó asociar la Teoría de la Complejidad y la Educación Integral para apoyar posibles articulaciones de las instituciones educativas formales con los diferentes espacios de su entorno. Como consideraciones finales, entendemos que el ser humano es parte de la tríada individuo/sociedad/especie, que pertenece a una comunidad y al mismo tiempo es el resultado de numerosas metamorfosis y evoluciones históricas, biológicas, culturales y sociales. Existen otros espacios y tiempos educativos, que directa o indirectamente contribuyen al desarrollo de las distintas capacidades de los sujetos que habitan el territorio.

PALABRAS CLAVE: Educación Integral. Edgar Morin. Espacios y tiempos educativos.

\section{INTRODUÇÃO}

Este trabalho apresenta um recorte do referencial teórico de uma dissertação de mestrado do Programa de Pós-Graduação em Educação da Universidade Federal do Triângulo Mineiro. A investigação que deu origem a esse trabalho foi desenvolvida no período entre 2018 e 2020, quando nos debruçamos em referenciais teóricos sobre a Educação Integral e os escritos de Edgar Morin sobre a Teoria da Complexidade.

Entendemos a Educação Integral como sendo uma concepção macro das políticas públicas, programas, projetos e ações de instituições e sistemas de ensino, repercutindo na configuração de outros espaços e tempos educativos e dos territórios em que elas estão inseridas, bem como na valorização e integração de dos saberes acadêmicos e saberes populares, os quais estão presentes em nosso cotidiano.

Ao desenvolver este trabalho tivemos como objetivo associar a Teoria da Complexidade e a Educação Integral para subsidiar possíveis articulação(ões) das instituições formais de ensino com os diferentes espaços do seu entorno.

Em um primeiro momento apresentamos um recorte das bases epistemológicas utilizadas para o trabalho, com foco na Teoria da Complexidade e suas contribuições para a concepção de Educação Integral. 
Posteriormente, a partir das contribuições apresentadas no primeiro tópico, desenvolvemos nosso pensamento quanto aos princípios pedagógicos da Educação Integral, especialmente quanto a valorização dos tempos e espaços educativos.

Por fim, entendemos que o ser humano compõe a tríade indivíduo/sociedade/espécie, o qual pertence a uma comunidade e ao mesmo tempo é resultado de inúmeras metamorfoses e evoluções históricas, biológicas, culturais e sociais. Há outros espaços e tempos educativos, os quais estão interligados e contribuem de maneira direta ou indireta para o desenvolvimento das diferentes capacidades dos sujeitos habitantes do entorno das instituições de ensino.

\section{EDUCAÇÃO INTEGRAL E EDGAR MORIN: SUBSÍDIOS PARA ESSA ASSOCIAÇÃO}

Encontramos nas produções de Edgar Morin subsídios epistemológicos para se ampliar os diálogos e encontrar outras interpretações quanto à Educação Integral enquanto concepção de Educação. Morin (2017, 2013, 2012, 2003, 2000), em suas obras, nos mostra o óbvio: 0 funcionamento indissociável das capacidades e dimensões do ser humano/espécie.

O autor (MORIN, 2015, 2012) descreve a maneira como os órgãos e as células do nosso corpo funcionam solidariamente, contribuindo, por exemplo, com o sistema imunológico, 0 sistema nervoso central, a oxigenação do sangue, a transmissão de códigos genéticos, 0 desenvolvimento das capacidades humanas entre outros.

O funcionamento e a cooperação celular são produtos de um longo processo evolutivo da espécie (MORIN, 2015), o qual teve início, mas não há fim. Estamos em constante mutação (MORIN, 2012). A nossa metamorfose é recursiva. Somos produtos e produtores de uma cadeia retroativa de ação-reação-ação a partir de nossas atitudes e/ou estímulos do meio. Conforme 0 autor "À maneira de ponto do holograma, trazemos no seio de nossa singularidade não somente toda a humanidade e toda a vida, mas também quase todo o cosmos, incluindo seu mistério que, sem dúvida, jaz no fundo da natureza humana" (MORIN, 2000, p. 51).

Influenciamos e somos influenciados pelas constantes mudanças do ambiente (MORIN, 2015). Esse processo não se limita ao corpo. São atos solidários, presentes

[...] nas trocas de informações entre as células corporais; a ordem e desordem cósmica, quando são estruturados novos corpos celestes a partir de poeiras e fragmentos de outros astros destruídos; a relação de auxílio, produção e transmissão de conhecimentos entre os povos, gerações e indivíduos, podendo influenciar na transformação ou permanência dos ritos, símbolos e organizações comunitárias. Sempre estamos em trocas solidárias e, na perspectiva da Educação Integral, a valorização e o fomento das capacidades humanas, sem sobreposição, e a incorporação de valores e saberes culturais são princípios fundamentais para 0 desenvolvimento do indivíduo. Aprendemos e ensinamos, formamos e estamos em 
formação pelos contatos estabelecidos entre o eu e nós (RIBEIRO, 2020, p. 60).

No entanto, precisamos identificar o contexto que nossa espécie se encontra. Para Morin (2012),

\begin{abstract}
Estamos numa segunda pré-história, idade de ferro planetária, pré-história de uma possivel sociedade-mundo, sempre pré-história do espírito humano, talvez préhistória da técnica...

Estamos em começos grosseiros: os primeiros policelulares eram muito menos complexos que as células neles associadas e só com o passar do tempo desenvolveram organização e geraram emergências e criatividade. Assim será, se ela vier a existir, com a sociedade-mundo.

As nossas consciências são subdesenvolvidas. Poderiam atingir níveis de elucidação e de complexidade superiores, controlar melhor os nossos atos, as nossas condutas, os nossos pensamentos e ajudar-nos a dialogar com as nossas ideias. Mas poderia sofrer regressões e perversões (MORIN, 2012, p.295).
\end{abstract}

Desconhecemos nossas potencialidades enquanto seres humanos/espécie. Não conhecemos todas as possibilidades do nosso Sistema Nervoso Central, como foi comprovado pela neurociência; nos afastamos de nossa humanidade e ainda temos os conflitos bélicos presentes no cotidiano, caracterizando a nossa Idade do Ferro (MORIN, 2012). O autor, em meio ao contexto descrito por ele, também nos convida a refletir:

Poderemos assumir o destino dialógico sapiens-demens, ou seja, manter a razão
sem ficar encerrados nela, conserva a loucura sem cair nela? Poderemos suportar a
situação neurótica do ser humano no mundo, consciente, ao mesmo tempo, de ser
tudo para si mesmo e nada no universo? Poderemos assumir a angústia do
inacabamento de nossas vidas e da incerteza do destino humano? Poderemos
aceitar ser abandonados pelos deuses? Poderemos abandoná-los? Saberemos que
somente o amor e a poesia vividos são respostas capazes de levar a enfrentar
angústia e mortalidade? Poderemos inibir a megalomania humana e regenerar o
humanismo? Poderemos fortalecer o mais precioso, o mais frágil, essas últimas
emergências que são o amor e amizade? Poderemos praticar a reforma interior que
nos tornaria melhores? Poderemos, um dia, "habitar poeticamente a Terra"? A
humanidade está em formação. Há possibilidades de rechaçar a barbárie e
realmente civilizar os humanos? Será possível transformar a hominização em
humanização? Será possivel salvar a humanidade, realizando-a? Nada está definido,
nem o pior (MORIN, 2012, p.295).

Para além de reconhecer o nosso inacabamento enquanto espécie/indivíduo/sociedade, o autor também nos impele a refletir sobre o planeta Terra enquanto pátria de todos os seres e que devemos atingir uma sociedade-mundo (MORIN, 2000), em prol de um bem comum de todos os seres coabitantes do orbe.

As transformações biológicas, culturais e sociais influenciam cada ser vivo que aqui habita. Enquanto Homo Sapiens-demens (MORIN, 2015, 2000), espécie que possui a razão ao mesmo tempo em que abriga em sim a loucura, desenvolvemos habilidades superiores às de outros seres viventes do planeta. No entanto, a subjugação, incompreensão, racionalidade, 
autojustificação e a disjunção dos saberes nos mantêm estagnados e impede que se efetive uma rede física e fraterna de interconectividade e que desenvolvamos o sentimento de pertença a este orbe (RIBEIRO, 2020).

Reconhecemos, com o apoio do pensador francês, a atual conjuntura planetária. A disjunção de povos, comunidades e saberes não tem contribuído para o avanço planetário e com a interligação dos conhecimentos em prol do desenvolvimento da humanidade.

Como nossa educação nos ensinou a separar, compartimentar, isolar e, não, a unir os conhecimentos, o conjunto deles constitui um quebra-cabeças ininteligível. As interações, as retroações, os contextos e as complexidades que se encontram na man's land entre as disciplinas se tornam invisíveis. Os grandes problemas humanos desaparecem em benefício dos problemas técnicos particulares. A incapacidade de organizar o saber disperso e compartimentado conduz à atrofia da disposição mental natural de contextualizar e de globalizar (MORIN, 2000, p.42-43).

Diante dessa emergência, Morin (2012) ilustra a importância de nos regenerarmos por meio de reformas capazes de nos aproxime uns dos outros, religando saberes, culturas e Estados-nação, tendo propósitos comuns, porém sem menosprezar ou negar as singularidades dos envolvidos. Tal processo, conforme 0 autor, nos levará a planetarização, em que ocorrerá a integração de culturas, saberes, indivíduos e seres vivos de forma solidária, simbiótica e ecológica, contrapondo o modelo mercadológico da sociedade atual.

Em busca de promover a ruptura do paradigma compartimentalizador deixado pelas Ciências Modernas, o autor defende três importantes reformas: a da vida; a da sociedade e a do pensamento, esta última desencadeada pela Educação, responsável pelo desenvolvimento dos seres humanos.

\begin{abstract}
Esse novo sistema permitira favorecer as capacidades da mente e pensar os problemas globais e fundamentais da pessoa e da sociedade na complexidade que possuem. Teria como alicerce a educação para a compreensão entre pessoas, povos e etnias. Um tal sistema de educação poderia e deveria desempenhar um papel civilizador. Reforma da educação e reforma do pensamento estimular-se-iam num círculo virtuoso. A reforma do espírito é um componente absolutamente necessário para todas as outras reformas. Leva a um modo de pensamento que permite compreender os problemas planetários e tomar consciência das necessidades políticas, sociais e peticas; isso é ainda mais importante na medida em que o papel da consciência humana é agora primordial para a salvação do planeta (MORIN, 2017, p. 170-171).
\end{abstract}

O autor, ao tratar da reforma do pensamento por meio da Educação, reconhecer que

[...] o espírito humano é capaz de praticar o conhecimento do seu próprio conhecimento, de incorporar os meios autocríticos e críticos que lhe permitam lutar contra os erros e ilusões, de não sofrer passivamente o imprinting da sua cultura,

Revista de Ciências Humanas, Frederico Westphalen - RS, , v. 22, n.1, p. 42-58, jan./abr. 2021. 
mas, ao contrário, de nutrir-se de sua cultura regenerada oriunda da união da cultura humanizada e da cultura científica; é capaz de não se deixar sequestrar por ideias mestras possessivas e autoritárias, de desenvolver e afirmar uma consciência ainda hesitante e demasiado frágil, enfim, de desenvolver suas potencialidades ainda não expressas. Sair da pré-história do espírito humano é necessário para sair da idade de ferro planetária, e sair da idade de ferro planetária é necessário para sair da préhistória do espírito humano (MORIN, 2017, p. 171).

Em meio aos subsídios fornecidos pelo pensador francês, encontramos na Educação as possibilidades de iniciar a reforma do pensamento e, consequentemente, da vida de e da sociedade. Por mais que a escola congregue as múltiplas singularidades e sujeitos em desenvolvimento, entendemos, no entanto, que o ato educativo não se restringe ao seu espaço.

Brandão (2007), em sua célebre contribuição, nos esclarece que

Ninguém escapa da educação. Em casa, na rua, na igreja ou na escola, de um modo ou de muitos todos nós envolvemos pedaços da vida com ela: para aprender, para ensinar, para aprender-e-ensinar. Para saber, para fazer, para ser ou para conviver, todos os dias misturamos a vida com a educação. Com uma ou com várias: educação? Educações. (p. 7-8).

Estamos em um constante processo de desenvolvimento, recebendo estímulos de nossos pares, espaços e tempos. 0 ensinar e o aprender são contínuos em nossas vidas. Não há tempo em que nos educamos e tempos em que não nos educamos (GADOTTI, 2009). A todos instante, em diferentes localidades, estamos aprendendo e ensinado.

É preciso reconhecer, ao tratarmos da Educação, que somos seres inteiros e, por isso, a Educação Integral neste artigo, significa para nós uma concepção das políticas públicas educacionais e, ao mesmo tempo, uma concepção de vida.

Nesse sentido, corroboramos com o posicionamento que considere o ser humano em sua inteireza, em que sejam desenvolvidas, horizontal e colaborativamente, as suas capacidades física, social, ética, estética, cognitiva, biológica, lúdica e física (GUARÁ, 2006).

No entanto, contrapomos a ideia de um desenvolvimento completo, holístico, em que se atinja a completude dos sujeitos por meio dos processos educativos como se esse fosse 0 ápice e objetivo final da Educação. Partindo do princípio que somos seres inacabados (MORIN, 2017), entendemos a Educação Integral

[...] como o desenvolvimento das potencialidades humanas e de suas capacidades, aceitando o nosso inacabamento, mas atuando, mesmo na incerteza do porvir, no fomento das possibilidades atuais e futuras de nossa evolução enquanto espécie e seres humanos (RIBEIRO, 2020, p. 61).

Assim, as contribuições de Morin (2017, 2013, 2012, 2003, 2000) nos ajudam a 
encontrar possíveis caminhos para as demandas emergentes da sociedade atual, especialmente quanto a Educação Integral dos seres humanos, considerando as relações ténues e incertas entre a separação e a integração dos saberes. A complexidade - aqui, de maneira simples, mas não simplifica, entendemos com a tessitura do conjunto (MORIN, 2015) - surge como resposta para romper com o modelo fragmentado de sociedade e Educação, propondo a aproximação entre os conhecimentos distanciados e dividido em hiperespecializações durante a modernidade; integração dos os espaços, setores, seres vivos e concebendo o ser humano como um ser integrado em seus aspectos biológicos, físicos, sociais, históricos e cósmicos (MORIN, 2012).

Para o pensador francês, além de nossa evolução biológica, cultural e social, carregamos em nossos genes a os produtos da ordem e da desordem universal, a qual, por meio dos inúmeros processos de transformação e formação de corpos celestes, possibilitou o nosso surgimento no planeta Terra.

\begin{abstract}
A origem da aventura cósmica nos é incompreensível; seu futuro, velado; seu sentido, desconhecido. Somos forjados, produzidos, levados nessa aventura da qual, na metade do século XX, ainda não tínhamos nenhuma consciência. A primeira lição que nos dá o cosmo é que as partículas dos átomos de nossas células apareceram nos seus primeiros segundos; nossos átomos de carbono formaram-se num sol anterior ao nosso; nossas macromoléculas uniram-se nos primeiros e convulsivos tempos da Terra, associando-se em turbilhões, entre os quais um, cada vez mais rico na sua diversidade molecular, metamorfoseou-se numa organização de novo tipo em relação à organização estritamente química: a auto-organização viva. [...] Um pouco de substância física organizou-se de modo termodinâmico na terra; através de imersão marinha, fervura química, descargas elétricas, ganhou vida. A vida é solar: todos os seus ingredientes foram forjados num sol e depois reunidos num planeta cujos componentes foram cuspidos por uma explosiva agonia solar; ela é a transformação de um corrimento fotônico oriundo de flamantes turbilhões solares (MORIN, 2012, p.26-27).
\end{abstract}

Em meio a toda essa organização biológica, cultural, cósmica e social que constitui a nós e ao nosso planeta, nos situamos em uma sociedade-mundo, em que transcendemos as fronteiras virtuais e terrestres, aproximando-nos uns dos outros. "Comungamos de princípios humanos semelhantes e, ao mesmo tempo, nos diferenciamos quanto aos modelos de vida, de sociedade, cultura e individualidade" (RIBEIRO, 2020, p.65).

Nesta perspectiva, a Educação Integral é uma concepção capaz de contribuir com 0 desenvolvimento dos seres humanos para despertarmos a consciência de que somos cidadãos terrestres e, paralelamente, de reconhecermos e valorizarmos a nossa identidade planetária, em que carregamos em nossos genes, hábitos, crenças e conhecimento de toda a evolução e metamorfose de nossa espécie e sociedade (MORIN, 2012).

Somos habitantes do mesmo orbe, o qual abriga toda a diversidade biológica, social e 
cultural existente. Aprendemos por meio das trocas e integrações, quando, em uma perspectiva intertranscultural, - em que superamos o divisionismo cultural e estabelecemos aproximação e integração entre as manifestações e diversidade existente (RIBEIRO, 2020) - nos propomos a reconhecer o valor e a cultura do outro, bem como a humanidade do eu, do outro para alcançarmos o nós.

Por fim, é preciso enfatizar: a educação, o desenvolvimento dos seres humanos não se restringe aos espaços escolares e familiares. Ao defendermos uma atitude complexa - no pensar e agir em sociedade por meio da aproximação dos campos do conhecimento e do reconhecimento da nossa integralidade - somos convidados a corroborar na existência de múltiplos espaços e tempos educativos, os quais não se limitam aos ambientes formais de ensino.

Há outros ambientes educadores: localidades, territórios, comunidades e sociedades, os quais contribuem de maneira direta ou indireta para o desenvolvimento integral dos seus habitantes. A cidade tem o potencial educador e acreditamos ser importante reconhecer isso. Tendo como subsídio a Teoria da Complexidade, não podemos pensar em uma sociedade fragmentada, com setores, população e instituições distanciados. Os espaços são vivos, dinâmicos e estão impregnados de diferentes culturas, saberes e educações (BRANDÃO, 2007).

\section{PRINCÍPIOS PEDAGÓGICOS DA EDUCAÇÃO INTEGRAL: VALORIZAÇÃO DE OUTROS TEMPOS E ESPAÇOS EDUCATIVOS}

Iniciamos, buscamos fundamentos legais para subsidiar nossas discussões, reconhecendo a Educação como direito de toda cidadã e cidadão brasileiro. Em busca de amparo legal, encontramos na Lei de Diretrizes e Bases da Educação Nacional (LDBEN), lei 9 394/96, especialmente no título que trata Dos Princípios e Fins da Educação Nacional, concepções e determinações quanto à organização das instituições de ensino no país. Nos artigos $2^{\circ}$ e $3^{\circ}$, a legislação determina

Art. 20 A educação, dever da família e do Estado, inspirada nos princípios de liberdade e nos ideais de solidariedade humana, tem por finalidade o pleno desenvolvimento do educando, seu preparo para o exercício da cidadania e sua qualificação para o trabalho.

Art. 300 ensino será ministrado com base nos seguintes princípios:

I - igualdade de condições para o acesso e permanência na escola;

II - liberdade de aprender, ensinar, pesquisar e divulgar a cultura, o pensamento, a arte e o saber;

III - pluralismo de ideias e de concepções pedagógicas;

IV - respeito à liberdade e apreço à tolerância; 
$V$ - coexistência de instituições públicas e privadas de ensino;

$\mathrm{VI}$ - gratuidade do ensino público em estabelecimentos oficiais;

VII - valorização do profissional da educação escolar;

VIII - gestão democrática do ensino público, na forma desta Lei e da legislação dos sistemas de ensino;

IX - garantia de padrão de qualidade;

$X$ - valorização da experiência extraescolar;

$\mathrm{XI}$ - vinculação entre a educação escolar, o trabalho e as práticas sociais;

XII - consideração com a diversidade étnico-racial; (BRASIL, 2017, p. 8-9).

A legislação apresenta aproximações com os pontos defendidos por Morin $(2017,2013$,

2012, 2003, 2000). Possibilitando, principalmente, o reconhecimento da espécie como Homo

Complexus.

\begin{abstract}
Somos seres infantis, neuróticos, delirantes e também racionais. Tudo isso constitui o estofo propriamente humano. 0 ser humano é um ser racional e irracional, capaz de medida e desmedida; sujeito de afetividade intensa e instável. Sorri, ri, chora, mas sabe também conhecer com objetividade; é sério e calculista, mas também ansioso, angustiado, gozador, ébrio, extático; é um ser de violência e de ternura, de amor e de ódio; é um ser invadido pelo imaginário e pode reconhecer o real, que é consciente da morte, mas que não pode crer nela; que secreta o mito e a magia, mas também a ciência e a filosofia; que é possuído pelos deuses e pelas Idéias, mas que duvida dos deuses e critica as Idéias; nutre-se dos conhecimentos comprovados, mas também de ilusões e de quimeras. E quando, na ruptura de controles racionais, culturais, materiais, há confusão entre 0 objetivo e 0 subjetivo, entre 0 real e 0 imaginário, quando há hegemonia de ilusões, excesso desencadeado, então o Homo demens submete o Homo sapiens e subordina a inteligência racional a serviço de seus monstros (MORIN, 2000, p.59-60).
\end{abstract}

Por isso, para o autor "[...] a educação deveria mostrar e ilustrar o Destino multifacetado do humano: o destino da espécie humana, o destino individual, o destino social, o destino histórico, todos entrelaçados e inseparáveis" (MORIN, 2000, p.61).

Nessa perspectiva, é preciso pensar na constituição de uma comunidade educativa. Entendemos comunidade como "[...] um conjunto de indivíduos ligados afetivamente por um sentimento de pertencimento a um Nós [...]" (MORIN, 2017, p.147). Na perspectiva educacional, os sujeitos estão ligados, afetivamente, pelos objetivos educacionais estabelecidos entre eles em busca de contribuir com o seu desenvolvimento e de seus pares.

Situados em um mundo cuja diversidade se faz presente em diferentes contextos, desde a expressão de ideias até as manifestações culturais e organizações sociais, a educação deve, em consonância com diferentes atores, promover a rede integrada e integradora de saberes, anseios, programas e propostas para o desenvolvimento dos educandos e o livre exercício dos docentes. Não há como descartar a educação do ser humano para o reconhecimento desta diversidade existente (RIBEIRO, 2020, p. 76).

Defendemos uma educação capaz de contribuir com o desenvolvimento dos seres humanos em prol de uma compreensão intelectual e humana, mesmo em um contexto de 
incertezas, ilusões e erros de um mundo em constante mutação.

A escola, enquanto instituição, compõe uma rede de espaços educativos que colaboram, direta ou indiretamente, com ou sem intencionalidades, no desenvolvimento dos sujeitos. No entanto, como elucida Brandão (2007), a educação está presente em outros espaços e tempos, não se restringindo ao ambiente escolar.

Assim, outros locais e momentos também colaboram com o desenvolvimento dos diferentes sujeitos. A multidimensionalidade humana não pode ser limitada aos espaços e tempos escolares. Ela se constitui de aspectos históricos, culturais, sociais e biológicos que se expande para outros momentos e locais do nosso cotidiano. É preciso educar em outros ambientes e em conjunto com os outros sujeitos que compõe a nossa sociedade.

A escola, no entanto, é o locus privilegiado e articulador das atividades educativas, quando nos referimos aos aspectos formais. Atua em prol da identidade terrestre - em que nos reconheçamos como seres pertencentes ao planeta Terra, carregando em nós os resultados evolutivos de nossa espécie, cultura e sociedade - nos educandos. É constituída por profissionais competentes, capazes de extrair os potenciais educativos de outros tempos e espaços, além de valorizar e incorporar os diferentes saberes nos projetos pedagógicos curriculares. Conforme Guará (2006),

Isoladamente, nenhuma norma legal, concepção ou área da política social dá conta do atendimento completo pretendido pelas propostas de educação integral. A perspectiva que adotamos é, portanto, a da necessidade de uma composição de estratégias e alternativas políticas e pedagógicas para repensarmos o modo de funcionamento das instituições educativas, a fim de colocá-las a favor da lógica da inclusão e da formação integral das crianças e adolescentes (p.15).

Gadotti (2009), em seus escritos, elucida que "A escola não pode fazer tudo o que a sociedade não está fazendo; ela não pode substituir as políticas sociais. A escola precisa cumprir bem a sua função de ensinar" (p.30). Para nós,

Ensinar já é um termo abrangente, engloba os conhecimentos construídos pela humanidade, antes divididos e, agora, emergem com a necessidade de reaproximálos por meio de uma sistematização. Na atualidade, as políticas públicas de proteção social (educação, saúde, segurança) encontram-se no ambiente escolar, o que nos cabe questionar qual tem sido, então, o real papel da escola na sociedade. Se abarca tudo, talvez possa não estar cumprindo a sua real função [...] (RIBEIRO, 2020, p.78).

Para Libâneo, Oliveira e Toschi (2012), a escola tem como

[...] objetivo explícito: o desenvolvimento das potencialidades físicas, cognitivas e

Revista de Ciências Humanas, Frederico Westphalen - RS, , v. 22, n.1, p. 42-58, jan./abr. 2021. 
afetivas dos alunos, por meio da aprendizagem de conteúdos (conhecimentos, habilidades, procedimentos, atitudes, valores), para se tornarem cidadãos participativos na sociedade em que vivem (p.419).

Partindo da afirmação de Guará (2006), precisamos reconhecer a escola como um dos espaços, privilegiados, capazes de contribuir com o desenvolvimento integral dos educandos, mas não o único. Há de se pensar na corresponsabilidade e potencialidade de outros setores, segmentos e atores da sociedade nesse processo: movimentos sociais, espaços da comunidade e da cidade (clubes, ruas, teatros, museus, praças, cinemas, bairros e etc), além de envolver outros cidadãos/habitantes que se tornam educadores, por serem mediadores do desenvolvimento de seus pares.

Além dos muros simbólicos das instituições de ensino há muito o que aprender e há muito a ser ensinado, por meio das relações mediatizadas pelo outro, pelos ambientes.

Com base nos estudos desenvolvidos por Moll (2012, 2009), Arroyo (2012), Gadotti (2009), Cavaliere (2007, 2002) e Guará (2006), encontramos alguns princípios pedagógicos para se pensar nas configurações de propostas e estratégias que tenham como concepção a Educação Integral.

Durante a nossa investigação (RIBEIRO, 2020), especialmente na tessitura do referencial teórico, encontramos como pilares basilares desta concepção a valorização e organização de: a) diferentes espaços e tempos; b) a relação entre escola e comunidade; c) a organização de currículos constituídos por saberes científicos e culturais; d) a intersetorialidade; e) a valorização dos educadores: professores e atores sociais.

A escola e outros espaços são símbolos de lutas, culturas, movimentos, resistências e história de uma comunidade/sociedade. São ambientes constituídos de complexidade, por difundirem e construírem conhecimentos. Por isso,

A escola pública precisa ser integral, integrada e integradora. Integrar ao Projeto Eco-Político-Pedagógico as igrejas, as quadras de esporte, os clubes, as academias de dança, de capoeira e de ginástica, os telecentros, parques, praças, museus, cinemas etc. além de, universidades, centros de estudos, Ongs e movimentos sociais, enfim, integrar o bairro e toda a municipalidade (GADOTTI, 2009, p.32-33).

O tempo não pode ser demarcado pela sineta que determina 0 início e o término das aulas, como se apenas ali ocorresse aprendizado. Além dos espaços, precisamos considerar e valorizar os outros momentos formativos vivenciados por nós que não se restringem ao ambiente escolar. 
na cidade se constitui num espaço cultural de aprendizagem permanente por si só [...] Não há educação integral sem a integração das diversas "educações" da cidade [...] (GADOTTI, 2009, p. 43).

Assim, alargam-se as possibilidades de desenvolvimento, mesmo com as singularidades das instituições frequentadas pelos sujeitos, os quais carregam bagagens culturais que são incorporadas ou (re)significadas durante a vida. É preciso reconhecer que

Toda escola está situada em uma comunidade com especificidades culturais, saberes, valores, práticas e crenças - 0 desafio é reconhecer a legitimidade das condições culturais da comunidade para estimular o diálogo constante com outras culturas (BRASIL, 2009a, 32-33).

Em uma sociedade-mundo, não há como separar o espaço de preparar para a vida e 0 espaço de viver a partir do aprendizado. "A maior parte do que sabemos aprendemos fora da escola. 0 que sabemos está vinculado tanto à escola quanto a sua primeira comunidade de aprendizagem, que é a família e o seu entorno" (GADOTTI, 2009, p.35).

Entendemos a Educação e o desenvolvimento integral do ser humano como fenômenos que acontecem a todo o instante, ao longo da nossa vida. A escola é mais um dos espaços que educam, pois apropriamos de conhecimentos durante a nossa convivência com os diferentes sujeitos e em diversos outros espaços (quadros, parques, museus e na própria rua) além dos escolares.

A diversidade presente nas comunidades é enraizada na identidade dos seus habitantes. A rotina impacta na constituição dos educandos enquanto sujeitos, os quais se apropriam destes conhecimentos por meio das relações estabelecidas por eles com os pares e o seu entorno ao longo de suas vidas.

Qualquer mundo, local ou global, é, ao mesmo tempo, educador e educando, como uma cidade ou um bairro, conectando, nessa educação, o formal, o informal e o não formal. A educação acontece durante toda a vida e em "todos os cantos". Por isso, a educação precisa ser integral e integradora (GADOTTI, 2009, p.47-48).

Com isso, escola e comunidade nem sempre são antagônicas. Podem ser complementares, possuindo o mesmo compromisso com o desenvolvimento integral dos sujeitos. Atuam com a intenção de fomentar nos educandos o sentimento de pertença, entendendo os sujeitos como sendo parte de um projeto maior, em que o alvo é a constituição de uma sociedade-mundo em que a identidade terrena deve ser o objetivo principal dos trabalhos promovidos pelos diferentes espaços. 
Ratifica-se, então, a ideia de ação intersetorial e de forte incidência na relação entre escola e comunidade, tendo por base a compreensão de que o projeto educativo das novas gerações deve radicar-se em um sólido compromisso entre os distintos atores que compõem o território em que a instituição escolar está situada (MOLL, 2012, p.138).

Os atores da comunidade educativa possuem saberes que desejam transmitir para os seus pares, os quais podem ser problematizados e incorporados nos projetos pedagógicos curriculares das instituições formativas. Por meio das relações, colaboram com 0 desenvolvimento uns dos outros. O currículo das instituições de ensino deve ser aberto para apropriação e incorporação de tais conhecimentos culturais em seus projetos pedagógicos, valorando as identidades, símbolos e outros aspectos históricos e culturais onde a escola está inserida.

\begin{abstract}
A educação deve, portanto, considerar esses saberes que garantem aos homens sua sobrevivência, seus relacionamentos pessoais e sociais, seu trabalho produtivo e 0 sentido para sua vida. Essas são tarefas de toda uma vida. Para dar conta delas, há um conjunto de conhecimentos sistematizados e organizados no currículo escolar e também há as práticas, habilidades, costumes, crenças e valores que conformam a base da vida cotidiana e que, somados ao saber acadêmico, constituem o currículo necessário à vida em sociedade (GUARÁ, 2006, p.17).
\end{abstract}

Os grupos e movimentos sociais, especialmente os que representam as minorias, clamam pelo reconhecimento e incorporação nos currículos escolares de seus saberes, histórias e lutas, deixando registrado os percursos e conquistas, tornando-as legítimas nos documentos norteadores das instituições formativas.

[...] pressionam por currículos de formação e de educação básica mais afirmativos dessas identidades coletivas. [...] para que entrem no território do conhecimento legítimo as experiências e saberes dessas ações coletivas, para que sejam reconhecidos sujeitos coletivos de memórias, história e culturas. Os movimentos sociais trazem indagações e disputas para o campo dos currículos e da docência (ARROYO, 2011, p.11).

Para além da valorização de outros espaços educativos, é preciso considerar e fortalecer a participação dos membros da comunidade na elaboração, desenvolvimento e avaliação de projetos pedagógicos e educativos que impactam direta e indiretamente na formação dos educandos e dos habitantes, que, como citado anteriormente, têm a escola e os profissionais da educação como agentes competentes para esse processo de mediação/articulação.

Em uma perspectiva democrática e participativa, é urgente reconhecer a importância, direito e dever de diferentes sujeitos, cidadãos, moradores do território, colaborarem com 0 
desenvolvimento dos seus pares, que culminará na transformação de suas realidades a curto, médio e longo prazo.

Os tempos, espaços e saberes culturais legitimados nos projetos pedagógicos são reconhecidos pelos sujeitos, os quais se tornam corresponsáveis pela educação de seus pares, por se sentirem representados em propostas pedagógicas que valoram suas trajetórias enquanto espécie e seres humanos.

O currículo, na perspectiva da Educação Integral, exprime as intencionalidades pedagógicas da comunidade educativa. Deve estar em diálogo com as diretrizes dos órgãos normatizadores, os interesses da comunidade, dos educandos, os saberes docentes e a concepção de ser humano defendida pelo coletivo (RIBEIRO, 2020, p. 81-82).

A responsabilidade pela formação dos educandos precisa ser compartilhada com outros setores, envolvendo as esferas públicas e outras instituições educativas, culturais, sociais e comunitárias. A escola sozinha não consegue fomentar e suprir o desenvolvimento integral e as necessidades dos sujeitos. É preciso unir esforços públicos e privados na tentativa de, em parceria, atender as demandas do ser humano em sua complexidade.

\footnotetext{
O princípio geral da educação integral é, evidentemente, como vimos, o da integralidade. $O$ conceito de integralidade refere-se à base da educação, que deve ser integral, omnilateral e não parcial e fragmentada. Uma educação integral é uma educação com qualidade sociocultural. A integração da cultura, da saúde, do transporte, da assistência social etc. com a educação possibilita a integralidade da educação (GADOTTI, 2009, p.97-98, grifo do autor).
}

A intersetorialidade não deslegitima e tampouco menospreza a atuação das instituições de ensino nas ações educativas. As escolas são articuladoras de todo o trabalho pedagógico a ser desenvolvido para se atingir os objetivos estabelecidos em comunhão com os segmentos das comunidades educativas. No entanto, é preciso reconhecer a importância e responsabilidade dos diferentes setores da administração pública para garantir os direitos constitucionais dos cidadãos.

\footnotetext{
Em uma perspectiva de sociedade-mundo e da complexidade humana, não há espaços para fragmentação de um trabalho voltado para a Educação Integral. É preciso a comunhão de políticas, programas, projetos e ações em prol do desenvolvimento dos educandos matriculados nas instituições de ensino. Os esforços não se restringem à escola. Enquanto cidadãos, é importante oportunizar viver a cidade em todos os sentidos, atendendo às necessidades de uma educação baseada na complexidade, por meio de ações pedagógicas, conjuradas para os mesmos fins (RIBEIRO, 2020, p. 82).
} 
Por fim, reconhecemos dentro desta perspectiva, a atuação de profissionais da Educação, licenciados, e outros agentes como importantes mediadores nesse processo. Os docentes são profissionais privilegiados, articuladores do currículo, dos saberes e tempos em prol desenvolvimento integral dos educandos. São capazes de extrair os potenciais educativos da localidade e valorizar as possibilidades oferecidas pelo território. Em contrapartida, os membros da comunidade podem e devem colaborar com a efetivação dos projetos construídos com seus pares, sob a orientação e coordenação das instituições de ensino. Conforme Guará (2006),

[...] a educação integral depende, sobretudo, de relações que visam à integração, seja de conteúdos, seja de projetos, seja de intenções. Num mundo cada vez mais complexo, a gestão das necessidades humanas e sociais exige a contribuição de múltiplos atores e sujeitos sociais, e uma nova cultura de articulação e a abertura dos projetos individuais para a composição com outros conhecimentos, programas e saberes (p.19).

Sob a ótica de uma sociedade-mundo e pela efetivação de políticas públicas que tenham como escopo a Educação Integral, precisamos reconhecer a existências de inúmeros educadores, profissionais da educação e os membros das comunidades, que são mediadores nos atos educativos em prol do desenvolvimento dos seres humanos. Nesta vertente, em nosso trabalho, entendemos que

Os sujeitos destes espaços são agentes culturais, educadores, os quais atuam como mediadores para fomentar nas crianças, jovens e adultos à apropriação de valores, crenças, hábitos, costumes e outras verdades sobre o mundo. Os territórios são beneficiados a partir do desenvolvimento de suas ações integradas, enveredados por um projeto tendo como concepção a Educação Integral (RIBEIRO, 2020, p. 80).

A participação de outros atores corrobora com a intenção de, na perspectiva de Morin (2012), se constituir uma sociedade-mundo. O objetivo não é desresponsabilizar os agentes públicos e instituições de ensino das suas funções sociais, mas efetivar uma proposta interligada com outros setores da sociedade e cidadãos para continuar contribuindo com o desenvolvimento do Homo Complexus.

\section{CONSIDERAÇÕES FINAIS}

Ao desenvolvermos este trabalho, durante a nossa dissertação, não tivemos a intenção de modificar os pensamentos consolidados quanto a concepção de Educação Integral, mas apresentar nossas percepções sobre o tema a partir da Teoria da Complexidade.

Entendemos o ser humano como uma espécie em desenvolvimento, a qual não atingiu 
as potencialidades biológicas, espirituais, físicas e sociais. Estamos em constante processo de mutação física, intelectual, cultural, comunitária, planetária e universal.

$\mathrm{Na}$ tentativa de associarmos esses dois temas, tratando especialmente sobre os diferentes tempos e espaços educativos, concluímos que o ser humano compõe a tríade indivíduo/sociedade/espécie, o qual pertence a uma comunidade e ao mesmo tempo é resultado de inúmeras metamorfoses e evoluções históricas, biológicas, culturais e sociais. Há outros espaços e tempos educativos que contribuem de maneira direta ou indireta para 0 desenvolvimento das diferentes capacidades dos sujeitos habitantes do território. Neste contexto, acreditamos na importância de se valorizar a cidade, sociedade e comunidade como igualmente educandas e educadoras, concebendo seus espaços e tempos como educativos.

\section{REFERÊNCIAS}

ARROYO, Miguel Gonzáles. O direito a tempos-espaços a um justo digno viver. In: MOLL, Jaqueline et al (Org.). Caminhos da Educação Integral no Brasil: direito a outros tempos e espaços educativos. Porto Alegre: Penso, 2012. Cap. 1. p. 33-45.

ARROYO, Miguel González. Currículo, território em disputa. 2. ed. Petrópolis: Vozes, 2011.

BRASIL. Rede de saberes mais educação: pressupostos para projetos pedagógicos de educação integral. Brasília: Ministério da Educação, 2009. 92 p. Disponível em:

<http://portal.mec.gov.br/dmdocuments/cad_mais_educacao_2.pdf>. Acesso em: 30 jul. 2020.

BRASIL. Constituição (1996). Lei no 9.394/1996 n 9394, de 20 de dezembro de 1996. Lei de Diretrizes e Bases da Educação Nacional. Brasília: Senado Federal, mar. 2017. Disponível em:

<http://www2.senado.leg.br/bdsf/bitstream/handle/id/529732/lei_de_diretrizes_e_bases_1ed.pdf> . Acesso em: 30 jul. 2020.

CAVALIERE, Ana Maria Vilela. Tempo de escola e qualidade na educação pública. Educação e Sociedade, Campinas, v. 28, n. 100, p.1015-1035, out. 2007. Mensal. Disponível em: <http://www.scielo.br/pdf/es/v28n100/a1828100>. Acesso em: 26 maio 2019.

CAVALIERE, Ana Maria Villela. Educação Integral: uma nova identidade para a escola brasileira?. Educação e Sociedade, Campinas, v. 23, n. 81, p.247-270, dez. 2002. Disponível em: <http://www.scielo.br/pdf/es/v23n81/13940.pdf>. Acesso em: 10 abr. 2019.

GADOTTI, Moacir. Educação Integral no Brasil: inovações e processos. São Paulo: Editora e Livraria Instituto Paulo Freire, 2009. Disponível em:

<http://acervo.paulofreire.org:8080/xmlui/bitstream/handle/7891/3079/FPF_PTPF_12_076.pdf>. Acesso em: 28 fev. 2019.

GUARÁ, Isa Maria F. Rosa. É imprescindível educar integralmente. Cadernos Cenpec | Nova
Série, [s.l.], v. 1, n. 2, p.15-24, 1 ago. 2006. Centro de Estudos e Pesquisas em Educação, 
Cultura e Ação Comunitária (CENPEC). http://dx.doi.org/10.18676/cadernoscenpec.v1i2. Disponível em: <http://cadernos.cenpec.org.br/cadernos/index.php/cadernos/issue/view/8>. Acesso em: 28 fev. 2019.

LIBÂNEO, José Carlos; OLIVEIRA, João Ferreira de; TOSCHI, Mirza Seabra. Educação Escolar: políticas, estrutura e organização. 10. ed. São Paulo: Cortez, 2012.

LIBÂNEO, José Carlos. Pedagogia e pedagogos, para quê? 12. ed. São Paulo: Cortez, 2010. $208 \mathrm{p}$.

MOLL, Jaqueline. A agenda da educação integral: compromissos para sua consolidação como política pública. In: MOLL, Jaqueline et al (Org.). Caminhos da Educação Integral no Brasil: direito a outros tempos e espaços educativos. Porto Alegre: Penso, 2012. Cap. 8. p. 129-146.

MOLL, Jaqueline. Educação integral: texto referência para o debate nacional. Brasília: Ministério da Educação, 2009. Disponível em: <http://portal.mec.gov.br/dmdocuments/cadfinal_educ_integral.pdf>. Acesso em: 28 fev. 2019.

MORIN, Edgar. 0 método 6: ética. 5. ed. Porto Alegre: Sulina, 2017. 224 p. Tradução de: Juremir Machado da Silva.

MORIN, Edgar. A via: para o futuro da humanidade. Rio de Janeiro: Bertrand Brasil, 2013. 392 p. Tradução de: Edgard de Assis Carvalho.

MORIN, Edgar. 0 método 5: a humanidade da humanidade. 5. ed. Porto Alegre: Sulina, 2012. 309 p. Tradução de: Juremir Machado da Silva.

MORIN, Edgar; CIURANA, Emilio-roger; MOTTA, Raúl Domingo. Educar na era planetária: 0 pensamento complexo como Método de aprendizagem no erro e na incerteza humana. São Paulo: Cortez, 2003. 111 p. Tradução de: Sandra TrabuccoValenzuela.

MORIN, Edgar. Os sete saberes necessários a educação do futuro. 2. ed. São Paulo: Cortez, 2000. Tradução de Catarina Eleonora F. da Silva e Jeanne Sawaya; revisão técnica de Edgard de Assis Carvalho.

RIBEIRO, Diovane de César Resende. Educação Integral e suas histórias: com a voz os professores da rede pública de ensino. 2020. 245 f. Dissertação (Mestrado) - Curso de Mestrado Acadêmico em Educação, Instituto de Educação, Letras, Artes e Ciências Humanas e Sociais, Universidade Federal do Triângulo Mineiro, Uberaba, 2020.

SANTOS, Boaventura de Sousa. Um discurso sobre as ciências. 5. ed. São Paulo: Cortez, 2008. $92 \mathrm{p}$. 